\title{
The Effect of Iron Deficiency Anemia on the Child Death Related to HIV/AIDS Infection: Meta-Analysis
}

\author{
Dyah Ambarwati'), Yulia Lanti Retno Dewi'), Bhisma Murti') \\ 1)Masters Program in Public Health, Universitas Sebelas Maret \\ ${ }^{2)}$ Faculty of Medicine, Universitas Sebelas Maret
}

\section{ABSTRACT}

Background: A quarter of the world's population suffers from iron deficiency anemia with various causes. Anemia has an impact on a child's quality of life, even if it is of mild or moderate severity. This study aims to analyze the effect of hemoglobin levels on the mortality of children infected with HIV/AIDS using a meta-analysis.

Subjects and Method: This was a systematic review and meta-analysis. Article searches were conducted using electronic databases, namely Google Scholar and PubMed. Article submission time is 1 month. Article search is done by several methods, namely boolean operators, handsearching, and keywords and MesH. The articles included in this study are articles that have a cohort study design. The systematics of article collection was carried out using the PRISMA-P flow chart. All articles were analyzed using the Review Manager 5.3.
Results: Hemoglobin $<10 \mathrm{~g} / \mathrm{dl}(\mathrm{aHR}=1.98$; 95\% CI=1.69 to 2.32; $\mathrm{p}<0.001)$, hemoglobin $<9$ $\mathrm{g} / \mathrm{dl} \quad(\mathrm{aHR}=1.79 ; \quad 95 \% \quad \mathrm{CI}=1.49$ to 2.14 ; $\mathrm{p}<0.001)$, and hemoglobin $<8 \mathrm{~g} / \mathrm{dl}(\mathrm{aHR}=1.77$; 95\% $\mathrm{CI}=1.43$ to $2.20 ; \mathrm{p}<0.001$ ) has an effect on mortality of children infected with HIV/AIDS.

Conclusion: Low hemoglobin levels increase the risk of death in children infected with HIV/AIDS.

Keywords: hemoglobin, anemia, iron, child death

\section{Correspondence:}

Dyah Ambarwati. Masters Program in Public Health, Universitas Sebelas Maret. Jl. Ir. Sutami 36A, Surakarta 57126, Central Java. Email: ambarwati.dyah27@gmail.com. Mobile: +6287735486570 .

\section{Cite this as:}

Ambarwati D, Dewi YLR, Murti B (2021). The Effect of Iron Deficiency Anemia on the Child Death Related to HIV/AIDS Infection: Meta-Analysis. J Epidemiol Public Health. 06(01): 157-168. https://doi.org/10.26911/jepublichealth.2021.06.02.03. (c) (i) (2) (-) Journal of Maternal and Child Health is licensed under a Creative Commons

\section{BACKGROUND}

Malnutrition is the leading cause of death in the world because it is the most complex health problem. Hemsley (2019) reports that 52 of the 462 million who are malnourished are children. Malnutrition in early life can pose a risk to quality of life across generations (Wells et al., 2019).

Children who experience acute malnutrition, three to nine times have a risk of experiencing physical and cognitive development disorders (Jerath et al., 2017). Chronic diseases in children will patho- physiologically increase the need for caloric intake, impaired nutrient absorption, problems with nutrient excretion, to the occurrence of intolerance of a type of nutrient (Nath et al., 2019). In general, people with HIV experience impaired nutrient absorption and chronic diarrhea (Duggal et al., 2012).

Iron deficiency anemia is experienced by $50 \%$ of children in the world with varying prevalence throughout the world, especially in developing countries. Anemia is a public health problem that has 
an impact on persistent changes in cognitive, motor, and neurocognitive performance (Roganovic et al., 2018). Anemia with mild or moderate severity has a risk of death (Allali et al., 2017).

Anemia is a prognostic and independent factor in the presence of Human Immunodeficiency Virus infection. Based on the WHO report, the highest prevalence of anemia is in children. Anemia in HIV/ AIDS sufferers is caused by nutritional imbalances, adherence to antiretroviral therapy, infection, and parenting (Beletew et al., 2020).

A study conducted by Shet et al. (2009) reported that the prevalence of anemia with hemoglobin levels of less than 11 $\mathrm{g} / \mathrm{dl}$ in HIV/AIDS children in South India was $66 \%$. Children infected with HIV/AIDS who live in rural areas are 12.04 times more likely to experience anemia than children with HIV/AIDS who live in urban areas. This is because the nutritional pattern during therapeutic intervention in children living in rural areas has not met the nutritional needs standards.

A cross sectional study conducted in Uganda reported on the prevalence and factors that influence anemia in children infected with HIV/AIDS. The highest prevalence of anemia was in children aged 6 to 24 months, which was 50.7\%. Factors associated with anemia in HIV/AIDS children are age less than 6 months, not taking multivitamins, history of blood transfusion, and malaria coinfection (Munyagwa et al., 2020).

The magnitude of anemia in HIVinfected children was found to be high in Ethiopia, which was $53.9 \%$. Children with clinical stages 3 and 4 have a 5.07 times risk of developing anemia. Children who experience moderate stunting are at risk of 5.16 times more prone to anemia. Children who experience severe stunting have a risk of 12.45 times more prone to anemia (Mulaw et al., 2020).

A meta-analysis study reported the prevalence of anemia in children with HIV/ AIDS in Ethiopia, which was 22.3\%. Comorbid anemia in children who started antiretroviral therapy was $0.4 \%$. Anemia causes a decrease in the quality of life of children (Wagnew et al., 2019).

Alebel (2020) conducted a study on the mortality rate of children living with HIV/ AIDS on antiretroviral therapy in northwestern Ethiopia. This study is a historical cohort study conducted on 538 children who were positive for HIV/AIDS. There are $45 \%$ of children with HIV/AIDS have opportunistic infectious diseases, namely diarrhea, pneumonia, and tuberculosis. Children who have clinical disease stage I and II are $57.6 \%$. The proportions of the initial nutritional status of children with HIV were $17.3 \%, 22.7 \%$, and $16.7 \%$, namely having very poor nutritional status, short, and thin. Based on the proportion of these nutrients, children who experience iron deficiency anemia during antiretroviral therapy are $12.3 \%$.

Various studies have been conducted to determine the incidence of anemia in children with HIV/AIDS and its effect on mortality. However, the results of these studies have not consistently found out how much anemia has an effect on child mortality. Further analysis is needed to rise at evidence-based conclusions on research that has been carried out in various countries. This study aimed to assess the effect of iron deficiency anemia on the mortality of children with HIV/AIDS.

\section{SUBJECTS AND METHOD}

\section{Study Design}

This was a meta-analysis study. Articles were obtained from electronic databases, namely Google Scholar and PubMed. 
Article collection is carried out for 1 month. The article search method uses the boolean operator, handsearching, keyword and MesH methods. The keywords used in this study were: "anemia", "anaemia", "haemoglobin", "hemoglobin", "iron deficiency anemia", "anemic", "HIV", "Human Immunodeficiency Virus", "HIV-positive" , "Child Mortality", "Mortality".

\section{Inclusion Criteria}

All research collected is a study with a cohort study design. The measure of the relationship is using the adjusted hazard ratio. The study population is children infected with HIV/AIDS with an age range of $\mathrm{o}$ to 18 years. Based on the PICO formula, the research intervention was hemoglobin levels $<10 \mathrm{~g} / \mathrm{dl}$, hemoglobin levels $<9 \mathrm{~g} / \mathrm{dl}$, and hemoglobin levels $<8$ $\mathrm{g} / \mathrm{dl}$. Comparative studies are hemoglobin levels $\geq 10 \mathrm{~g} / \mathrm{dl}$, hemoglobin levels $\geq 9 \mathrm{~g} / \mathrm{dl}$, and hemoglobin levels $\geq 8 \mathrm{~g} / \mathrm{dl}$.

\section{Exclusion Critera}

Articles are excluded if the article cannot be accessed by full paper, articles that are accessible but incomplete, and articles that use languages other than English.

\section{Operational Definition of Variables} The formulation of the research problem was carried out using PICO. Population is children with HIV/AIDS who are in the age range 0 to 18 years. Interventions were hemoglobin levels <10 g/dl, hemoglobin levels $<9 \mathrm{~g} / \mathrm{dl}$, and hemoglobin levels $<8$ $\mathrm{g} /$ dl. Comparison are hemoglobin levels $\geq$ $10 \mathrm{~g} / \mathrm{dl}$, hemoglobin levels $\geq 9 \mathrm{~g} / \mathrm{dl}$, and hemoglobin levels $\geq 8 \mathrm{~g} / \mathrm{dl}$. Outcomes are death.

Iron Deficiency Anemia is a hemoglobin concentration in the blood that is less than $11 \mathrm{~g} / \mathrm{dl}$.

Death is the death status of a child with
HIV/AIDS based on what is recorded in the medical record stated by a professional, a death certificate, or a verbal autopsy.

HIV/AIDS is a spectrum of diseases that attack the immune system, causing a primary infection that begins without showing symptoms until at an advanced stage it can cause disease complications.

\section{Data Analysis}

Research data processing is carried out using the Review Manager 5.3 application (RevMan 5.3) by calculating the adjusted Hazard Ratio and heterogeneity values to determine the research model and produce meta-analysis research in the form of forest plots.

\section{RESULTS}

Research from primary studies related to the effect of iron deficiency anemia on child mortality with HIV/AIDS consisted of 14 studies from 12 studies from the African continent and 2 studies from the Asian continent. Figure 1 shows the region of the retrieved articles that fit the inclusion criteria. Furthermore, the researchers conducted an assessment of the quality of the articles and there were 14 cohort study articles.

The systematic search for the article is to use a database, which can be seen in the flowchart of Figure 1.

The research area which is the location of the research carried out, covers 2 continents, namely the African continent and the Asian continent. The research area of meta-analysis can be seen in Figure 2. 


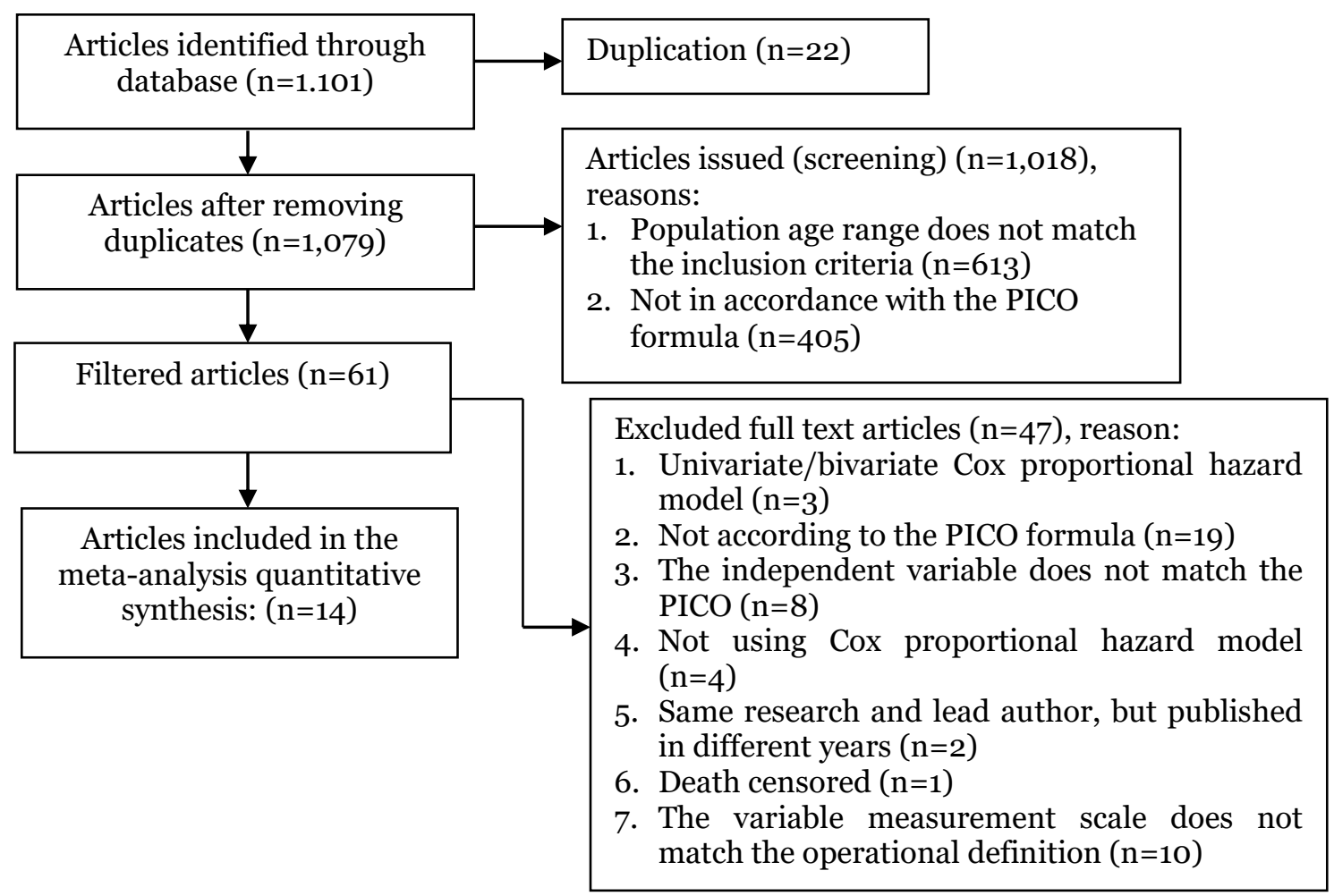

\section{Figure 1. Flowchart of the article search process}

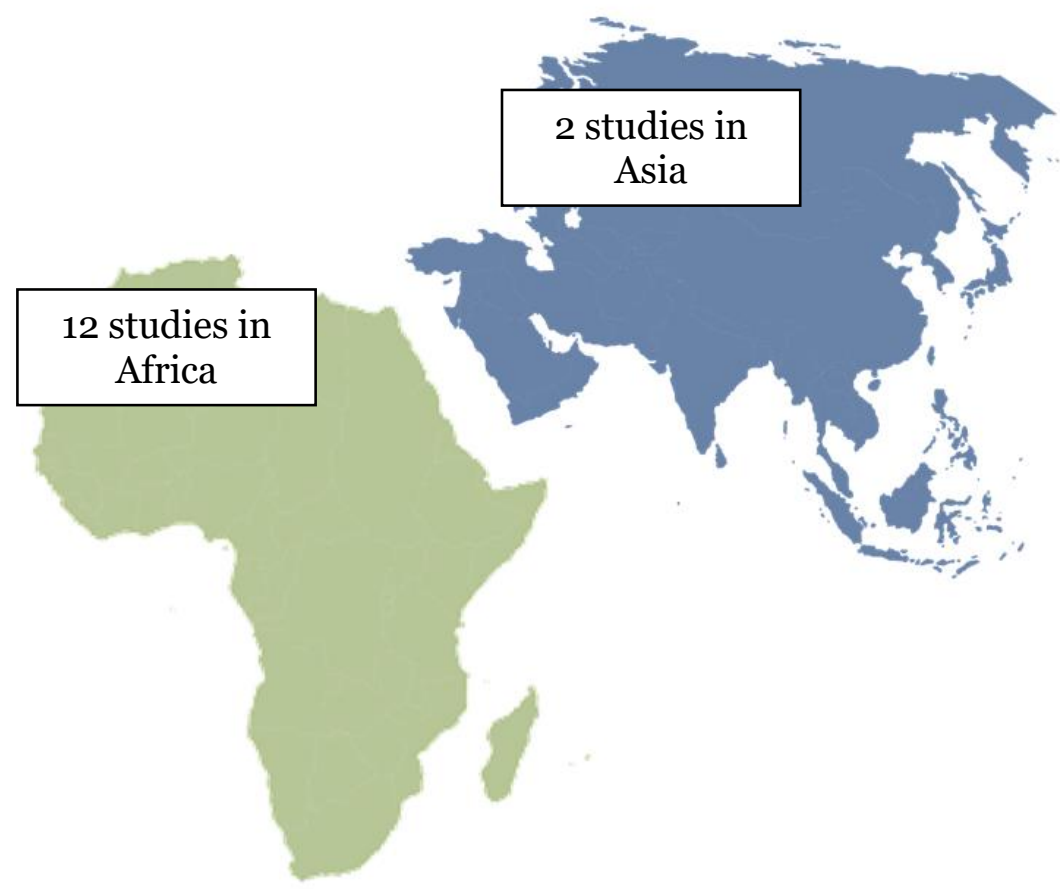

Figure 2. Research Area Map Region 
1. Hemoglobin Level $<10 \mathrm{~g} / \mathrm{dl}$

There are 14 research articles on mortality in children infected with HIV/AIDS with hemoglobin levels $<10 \mathrm{~g} / \mathrm{dl}$ using the adjusted hazard ratio and $95 \%$ confidence interval.

\section{a. Forest Plot}

Forest plot of hemoglobin levels $<10 \mathrm{~g} / \mathrm{dl}$ on mortality of children infected with HIV/AIDS can be seen in Figure 3 below.

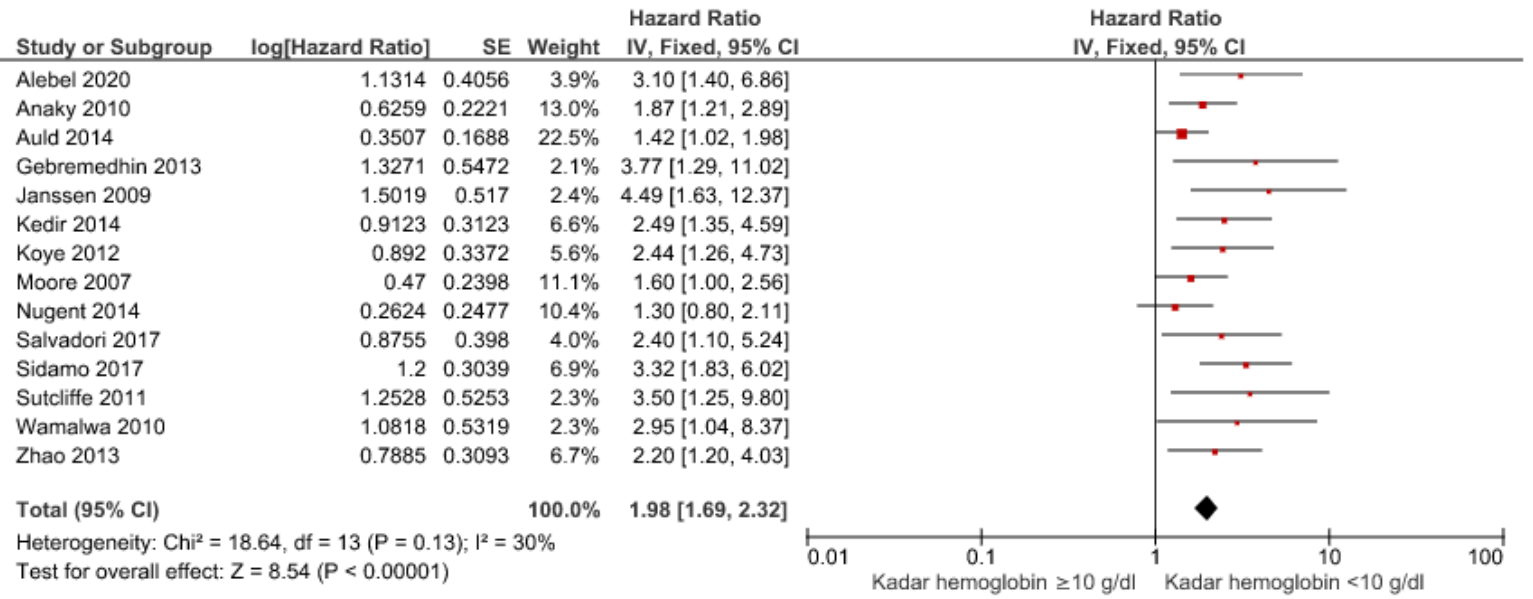

\section{Figure 3. Forest plot of hemoglobin $<10 \mathrm{~g} / \mathrm{dl}$ on mortality of children infected with HIV/AIDS}

Based on the results of the forest plot, there was an effect of hemoglobin levels of $<10$ $\mathrm{g} / \mathrm{dl}$ on the mortality of children infected with HIV/AIDS with a pooled hazard ratio value of 1.98 with a 95\% CI range of 1.69 to 2.32 which was statistically significant. The analytical model used is the Fixed Effect Model with a variation value of $30 \%$. This means that children infected with HIV/

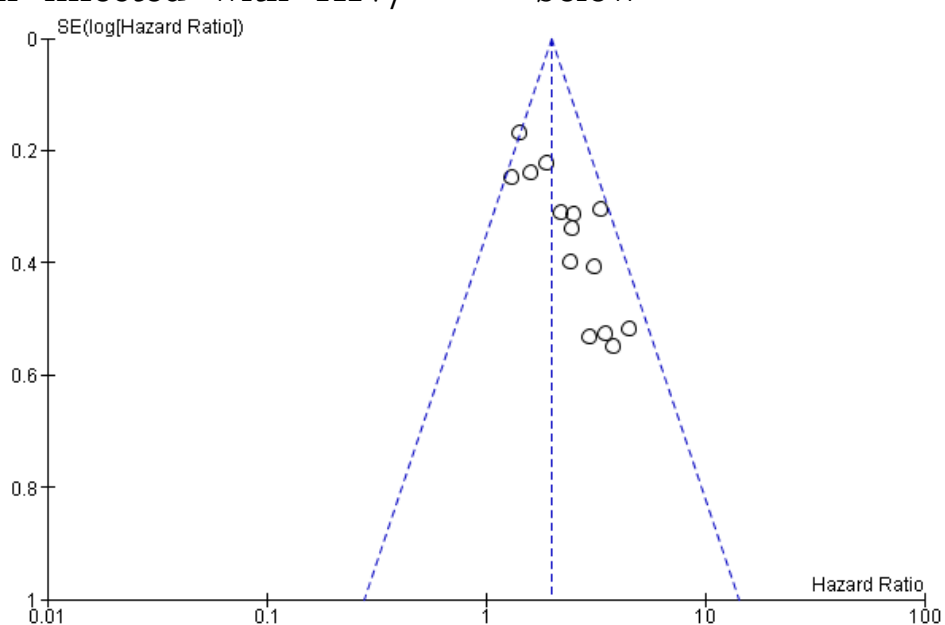

Figure 4. Funnel Plot the effect of hemoglobin levels $<10 \mathrm{~g} / \mathrm{dl}$ to the death of children infected with HIV/AIDS
AIDS with hemoglobin levels $<10 \mathrm{~g} / \mathrm{dl}$ have a 1.98 times risk of dying compared to children infected with HIV with hemoglobin levels $\geq 10 \mathrm{~g} / \mathrm{dl}$.

\section{b. Funnel Plot}

The funnel plot of hemoglobin levels $<10$ $\mathrm{g} / \mathrm{dl}$ on the mortality of children infected with HIV/AIDS can be seen in Figure 4 below 
right plot is not balanced, the distance in each plot is far. The plot on the left has a standard error (SE) in the range 0.18 to 0.26. The plot on the right has a standard error (SE) in the range of 0.32 to 0.58 . This shows that there is a publication bias in the study. Effect of hemoglobin levels $<10 \mathrm{~g} / \mathrm{dl}$

\section{a. Forest Plot}

The forest plot of hemoglobin levels $<9$ $\mathrm{g} / \mathrm{dl}$ on the mortality of children infected on mortality of children with HIV/AIDS infection.

\section{Hemoglobin Level $<9$ g/dl}

There are 10 research articles on mortality in children infected with HIV/AIDS with hemoglobin levels $<9 \mathrm{~g} / \mathrm{dl}$ using the adjusted hazard ratio and $95 \%$ confidence interval.

with HIV/AIDS can be seen in Figure 5 below.

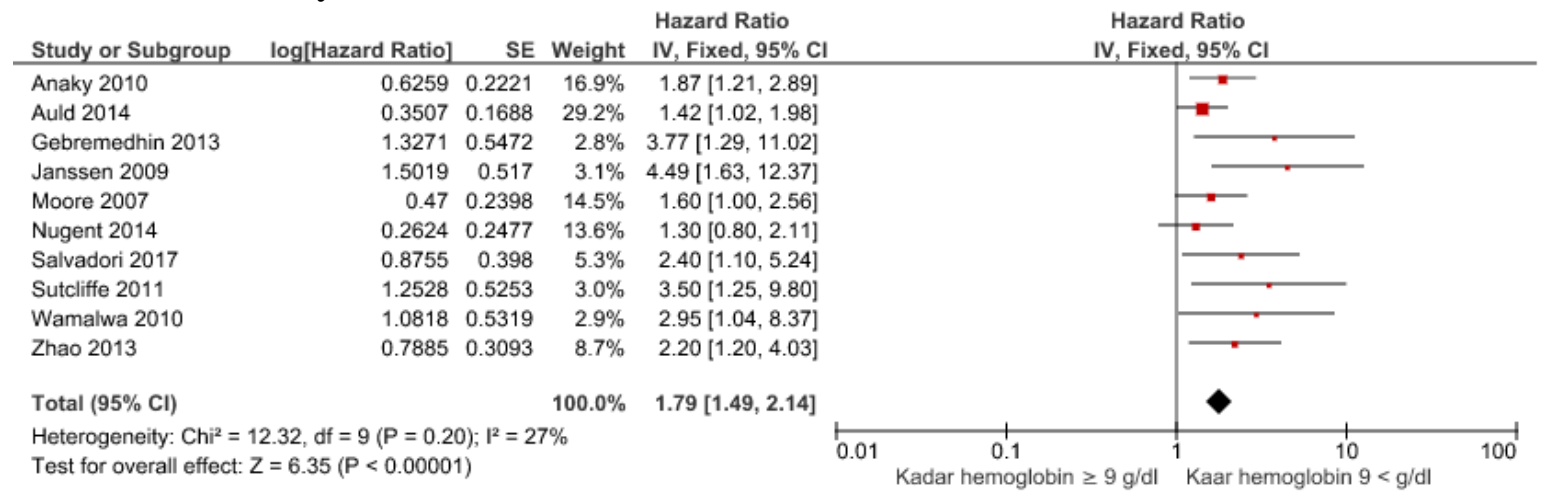

Figure 5. Forest plot of hemoglobin $<9 \mathrm{~g} / \mathrm{dl}$ on mortality of children infected with HIV/AIDS

Based on the results of the forest plot, there is an effect of hemoglobin levels of $<9 \mathrm{~g} / \mathrm{dl}$ on the mortality of children infected with HIV/AIDS with a pooled hazard ratio of 1.79 with a 95\% CI ranging from 1.49 to 2.14 which is statistically significant. The analytical model used is the Fixed Effect Model with a variation value of $27 \%$. This means that children infected with HIV/AIDS with hemoglobin levels $<9 \mathrm{~g} / \mathrm{dl}$ have a 1.79 times risk of dying compared to children infected with HIV with hemoglobin levels $\geq 9 \mathrm{~g} / \mathrm{dl}$.

\section{b. Funnel Plot}

The funnel plot of hemoglobin levels $<9$ $\mathrm{g} / \mathrm{dl}$ on the mortality of children infected with HIV/AIDS can be seen in Figure 6.

Figure 6 shows an asymmetrical funnel plot with an unbalanced distribution of research results on the left and right plots. There is 3 plots to the left of the center line and 7 plots to the right of the center line. The plot on the left has a standard error (SE) in the range of 0.16 to 0.26. The plot on the right has a standard error (SE) in the range of 0.24 to 0.58 . This shows that there is a publication bias in the study. Effect of hemoglobin levels $<9 \mathrm{~g} / \mathrm{dl}$ on mortality of children with HIV/AIDS infection. 
Ambarwati et al./ Iron Deficiency Anemia on the Child Death Related to HIV/AIDS Infection

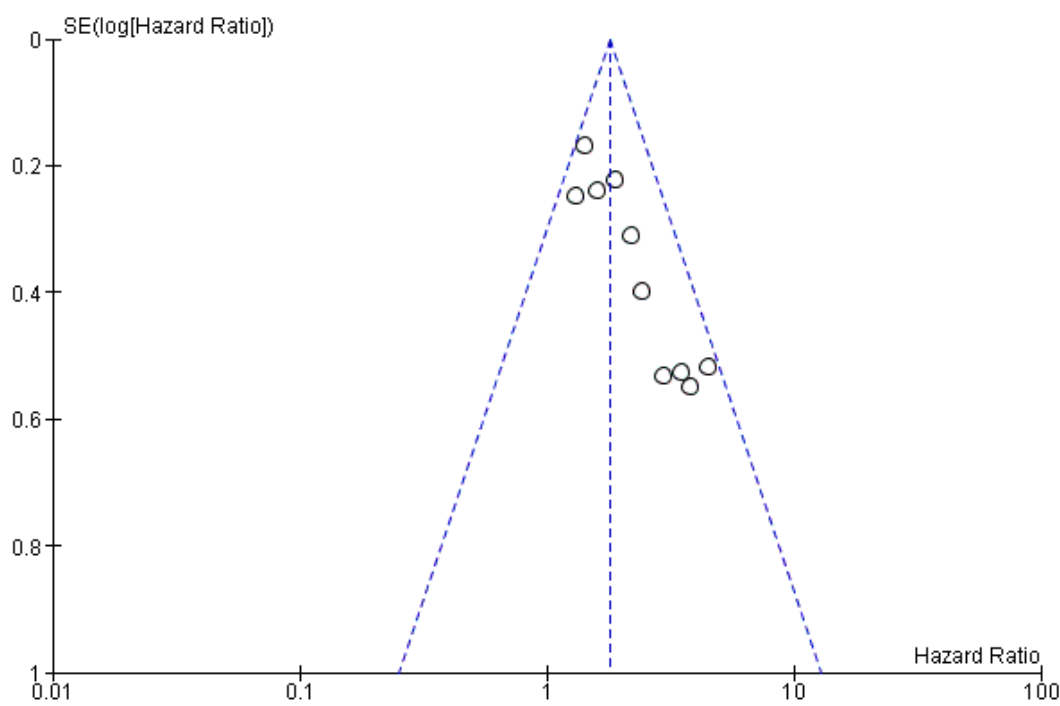

Figure 6.Funnel Plot of the effect of hemoglobin levels $<9 \mathrm{~g} / \mathrm{dl}$ on the mortality of children infected with HIV/AIDS

\section{Hemoglobin Level $<8$ g/dl}

There are 6 research articles on mortality in children infected with HIV/AIDS with

\section{a. Forest Plot}

Forest plot of hemoglobin levels $<8 \mathrm{~g} / \mathrm{dl}$ on hemoglobin levels $<8 \mathrm{~g} / \mathrm{dl}$ using the adjusted hazard ratio and $95 \%$ confidence interval. mortality of children infected with HIV/ AIDS can be seen in Figure 7 below.

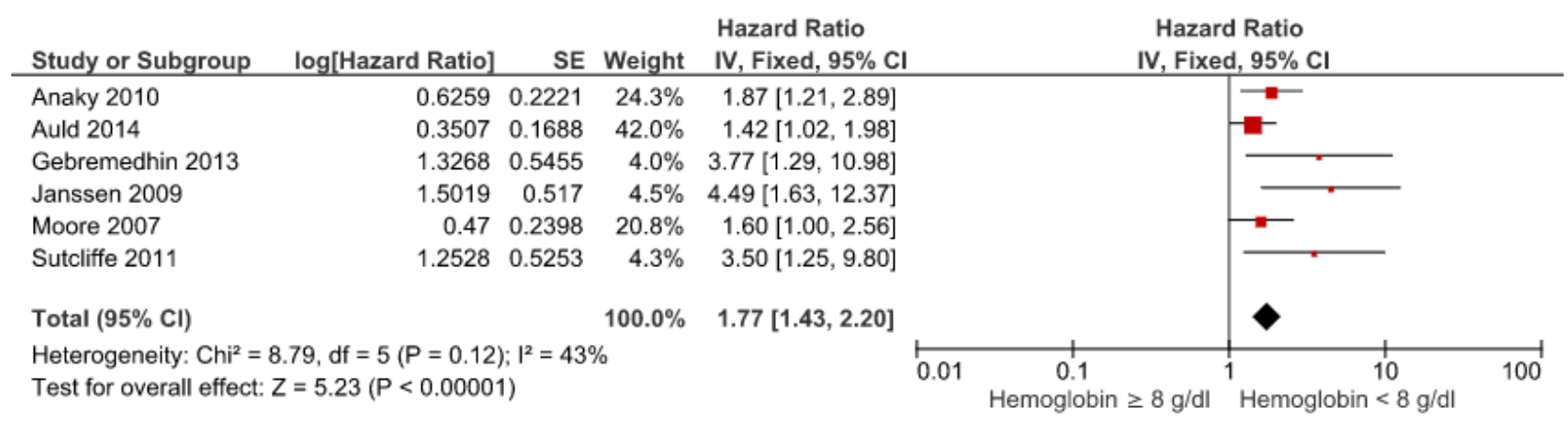

Figure 7. Forest plot of hemoglobin $<8 \mathrm{~g} / \mathrm{dl}$ on mortality of children infected with HIV/AIDS 
Based on the results of the forest plot, there was an effect of hemoglobin levels of $8 \mathrm{~g} / \mathrm{dl}$ on the mortality of children infected with HIV/AIDS with a pooled hazard ratio of 1.77 with a 95\% CI ranging from 1.43 to 2.20 which was statistically significant. The analytical model used is the Fixed Effect Model with a variation value of $43 \%$. This means that children infected with HIV/AIDS with hemoglobin levels $<8 \mathrm{~g} / \mathrm{dl}$ have a 1.77 times risk of dying compared to children infected with HIV with hemoglobin levels $\geq 8 \mathrm{~g} / \mathrm{dl}$.

\section{b. Funnel Plot}

The funnel plot of hemoglobin levels $<8$ $\mathrm{g} / \mathrm{dl}$ on the mortality of children infected with HIV/AIDS can be seen in Figure 8.

Figure 8 shows an asymmetrical funnel plot with an unbalanced distribution of research results on the left and right plots. There are 2 plots to the left of the center line and 4 plots to the right of the center line. The plot on the left has a standard error (SE) in the range 0.18 to 0.24. The plot on the right has a standard error (SE) in the range of 0.22 to 0.58 . This indicates that there is a publication bias in the study of the effect of hemoglobin levels $<8 \mathrm{~g} / \mathrm{dl}$ on the mortality of children with HIV/AIDS infection.

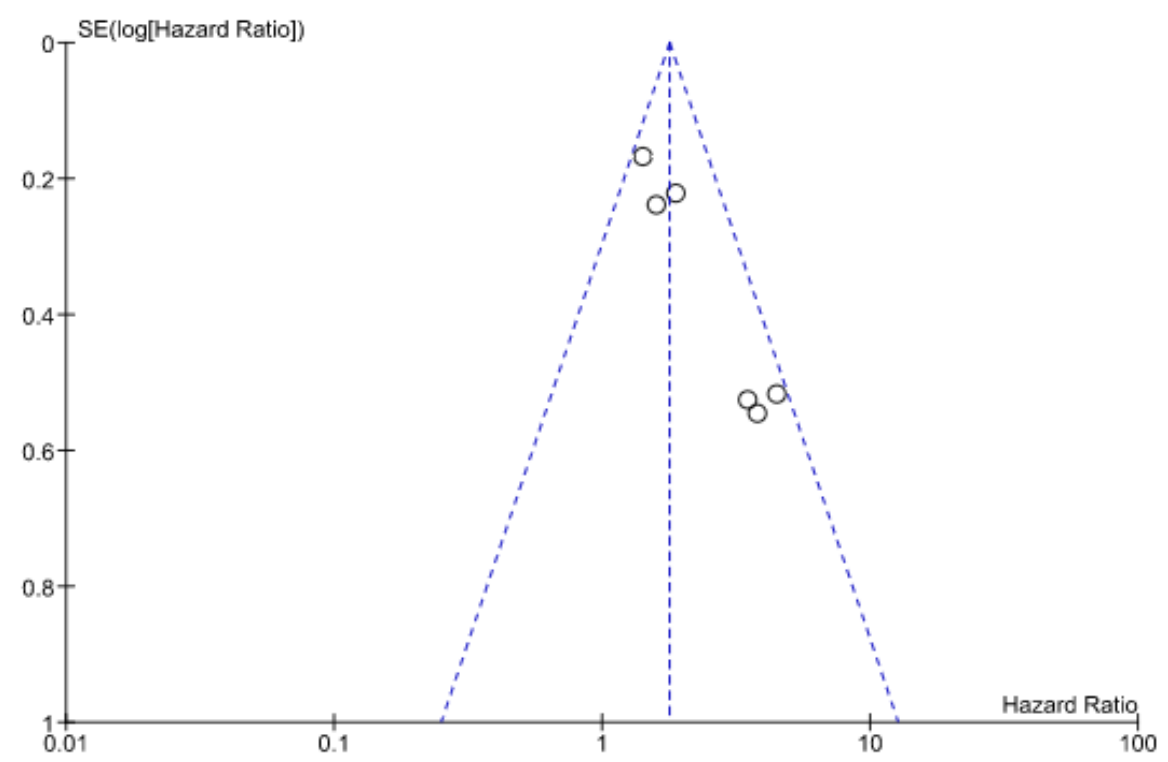

\section{Figure 8. Funnel Plot of the effect of hemoglobin levels $<8 \mathrm{~g} / \mathrm{dl}$ on the mortality of children infected with HIV/AIDS}

\section{DISCUSSION}

Iron has several important functions for the body, namely as a catalyst for oxygenation, helping the body's metabolism, hydroxylation, nucleic acid synthesis, and being a cofactor for enzymes in mitochondrial respiration. Beletew et al. (2020) reported that the factors that influence anemia in children undergoing antiretroviral therapy are amebiasis, opportunistic diseases, malnutrition, non-adherence to antiretroviral therapy, originating from rural areas, and consuming a non-diversified diet.

Opportunistic diseases have an important role in the incidence of malnutrition in children with HIV/AIDS. Opportunistic diseases have common symptoms such as decreased appetite, impaired absorption of nutrients, gastrointestinal disease, or inflammation. Based on the WHO report in 2013, 0.4 of the 1.5 million deaths due to tuberculosis were 
people with HIV/AIDS. Anemia and malnutrition are common complications experienced by tuberculosis patients.

Iron has a role as a growth factor for Mycobacterium tuberculosis. Anemia that occurs in tuberculosis patients is due to metabolic changes, changes in leptin concentrations in the blood, and cachexia. This has a risk of death (Nasution, 2015). Children receiving antiretroviral therapy with opportunistic diseases were 10 times more likely to have anemia than children without opportunistic diseases.

Impaired nutrient absorption that causes malnutrition in children with HIV/AIDS is related to the incidence of iron deficiency anemia. Impaired absorption of nutrients in children can occur due to damage to the intestinal villus. The carbohydrates and fats needed cannot be absorbed through the capillaries and lymphatics that are part of the intestinal villus. Fat is one of the solvents for several vitamins, such as $\mathrm{A}, \mathrm{D}, \mathrm{E}$, and $\mathrm{K}$. The impaired absorption causes the levels of vitamins that the body needs are not met properly. This is related to low levels of vitamin A. Vitamin A has a function as a transporter of erythrophides and iron (Duggal et al., 2012).

Antiretroviral adherence is associated with improved virological, immunologic, and clinical outcomes. The benefits of antiretrovirals will be maximized if adherence is more than 95\% (WHO, 2006). Immunological improvement is very important to improve nutritional status. Banna et al. (2019) reports that there is a significant relationship between adherence to antiretroviral therapy and the quality of life of people living with HIV/AIDS.

Anemia can be caused by environmental factors. Rural areas, low economic levels, and remote locations are more at risk of developing iron deficiency anemia.
The breakdown of family structures and the failure of social and health systems can be socioeconomic factors for malnutrition (Sashindran et al., 2020). This can be caused because there is food insecurity so that the daily nutritional adequacy is not met. Limited resources result in iron deficiency, folic acid, and vitamin A. Children with HIV/AIDS require higher daily needs than children who are not infected with HIV/AIDS (Shet et al., 2009).

\section{AUTHOR CONTRIBUTION}

Dyah Ambarwati was the lead author who selected the topic, conducted an article search, and collected all the data needed for this meta-analysis. Yulia Lanti Retno Dewi played a role in reviewing research data. Bhisma Murti played a role in analyzing research data.

\section{FUNDING AND SPONSORSHIP}

This study is self-funded.

\section{CONFLICT OF INTEREST}

There is no conflict of interest in this study.

ACKNOWLEDGEMENT

We thank the providers of data on electronic databases, especially Google Scholar and PubMed.

\section{REFERENCES}

Alebel A, Engeda EH, Kelkay MM, Petrucka P, Kibret GD, Wagnew F, Eshetie S (2020). Mortality rate among HIVpositive children on ART in Northwest Ethiopia: A historical cohort study. BMC Public Health, 20(1), 111. https://doi.org/10.1186/s12889020-09418-6

Allali S, Brousse V, Sacri A, Chalumeau M, Montalembert Mde (2017). Expert Review of Hematology Anemia in children: prevalence, causes, diagnos- 
Ambarwati et al./ Iron Deficiency Anemia on the Child Death Related to HIV/AIDS Infection

tic work-up, and long-term consequences. Expert Review of Hematology, 10(11), 1023-1028. https://doi.org/10.1080/17474086.2017.1354696

Anaky MF, Duvignac J, Wemin L, Kouakoussui A, Karcher S, Touré S, Leroy V. (2009). Scaling up antiretroviral therapy for HIV-infected children in côte d'ivoire: Determinants of survival and loss to programme. Bulletin of the World Health Organization, 88(7): 490-500. https://doi.org/10.2471/BLT.09.068015.

Auld AF, Tuho MZ, Ekra KA, Shiraishi RW, Mohamed F, Kouakou JS, Ellerbrock TV (2014). Temporal trends in mortality and loss to follow-up among children enrolled in côte d'ivoire's national antiretroviral therapy program. Pediatric Infect Dis J, 33(11), 1134-1140. https://doi.org/10.1097/INF.0000000000000457.

Banna T, Manoppo IA (2019). Kualitas hidup orang dengan HIV dan AIDS (ODHA) ditinjau dari kualitas hidup orang dengan HIV dan AIDS (ODHA) ditinjau dari kepatuhan minum obat antiretroviral (ARV) (Quality of life of people living with HIV and AIDS (PLWHA) in terms of adherence to taking antiretroviral drugs (ARVs)). Wellness And Healthy Magazine, 1(February), 1-6.

Beletew B, Mengesha A, Ahmed M, Fitwi A, Wudu M (2020). Determinants of anemia among HIV-Positive Children on highly active antiretroviral therapy attending hospitals of North Wollo Zone, Amhara Region, Ethiopia, 2019: A case-control study. Hindawi Anemia, 1-10.

Duggal S, Chugh TDas, Duggal AK. (2012). HIV and malnutrition: Effects on immune system. Clin Develop
Immunology, 2012. https://doi.org/$10.1155 / 2012 / 784740$

Gebremedhin A, Gebremariam S, Haile F, Weldearegawi B, Decotelli C. (2013). Predictors of mortality among HIV infected children on anti-retroviral therapy in Mekelle Hospital, Northern Ethiopia: A retrospective cohort study. BMC Public Health, 13(1). https://doi.org/10.1186/1471-245813-1047

Hemsley S. (2019). Malnutrition is a world health crisis, says WHO expert (Dr. Francesco Branca). Retrieved March 12, 2021, from https://www.globalcause.co.uk/world-food-day/malnutrition-is-a-world-health-crisis-sayswho-expert/

Janssen N, Ndirangu J, Newell ML, Bland RM (2009). Successful paediatric HIV treatment in rural primary care in Africa. Arch Dis Childhood. 95(6): 414-421. https://doi.org/10.1136/adc.2009.169367

Jerath SG, Singh A, Jerath N, Gupta S \& Racine EF. (2017). Undernutrition and severe acute malnutrition in children. The BMJ, 1-6.

Kedir AA, Desta A, Fesseha G. (2014). Factors affecting survival of HIV positive children taking antiretroviral therapy at Adama referral hospital and medical college, Ethiopia. Journal of AIDS and Clinical Research, 5(3). https://doi.org/10.4172/2155-6113.1000289

Koye DN, Ayele TA, Zeleke BM (2012). Predictors of mortality among children on Antiretroviral Therapy at a referral hospital, Northwest Ethiopia: A retrospective follow up study. BMC Pediatrics, 12. https://doi.org/10.1186/1471-2431-12-161

Moore CB, Mbewe MM, Cantrell RA, Chintu N, Stringer EM, Chi BH, Stringer 
Ambarwati et al./ Iron Deficiency Anemia on the Child Death Related to HIV/AIDS Infection

JSA (2007). Clinical outcomes and CD4 cell response in children receiving antiretroviral therapy at primary health care facilities in Zambia. J Am Med Assoc. 298(16): 1888-1899. https://doi.org/10.1001/jama.298.16.1888.

Mulaw GF, Yesuf FA, Abebe HT (2020). Magnitude of anemia and associated factors among HIV-infected children receiving antiretroviral therapy in Pastoral community, Ethiopia: A retrospective cross-sectional study. Advances in Hematology, 2020, 9-12. https://doi.org/10.1155/2020/96439 o1.

Munyagwa M, A Mworozi E, Ndeezi G, Mulumba Y, Ssali F (2020). Anaemia in HIV-Infected Children in A National Referral Hospital in Uganda: Prevalence and Associated Factors. Acta Scientific Med Sci. 4(3): 01-07. https://doi.org/10.31080/asms.2020. 04.0556.

Mutanga JN, Mutembo S, Ezeamama AE, Song X, Fubisha RC, Mutesu-Kapembwa K, Whalen CC (2019). Long-term survival outcomes of HIV infected children receiving antiretroviral therapy: An observational study from Zambia (2003-2015). BMC Public Health, 19(1): 1-12. https://doi.org/10.1186/s12889-019-6444-7.

Nasution SD (2015). Malnutrisi dan anemia pada penderita tuberkulosis paru (Malnutrition and anemia in patients with pulmonary tuberculosis). Majority, 4(8): 29-36.

Nath CL, Goday P (2019). Malnutrition in Children With Chronic Disease. Nutrition in Clinical Practice, 34(3), 349-358.

https://doi.org/10.1002/ncp.10274

Nugent J, Edmonds A, Lusiama J, Thompson D, Behets F (2014). Predicting mortality in HIV-infected children initiating highly active antiretroviral therapy in a resource-deprived setting. Pediatric Infect Dis J. 33(11), 1148-1155. https://doi.org/10.1097/INF.0000000000000454.

Oumer A, Kubsa ME, Mekonnen BA. (2019). Malnutrition as predictor of survival from anti-retroviral treatment among children living with HIV/AIDS in Southwest Ethiopia: Survival analysis. BMC Pediatrics, 19(1). https://doi.org/10.1186/s12887-019-1823-x.

Rajasekaran S, Jeyaseelan L, Ravichandran N, Gomathi C, Thara F, Chandrasekar $C$ (2008). Efficacy of antiretroviral therapy program in children in India: prognostic factors and survival analysis. Acad Oup Com. https://academic.oup.com/tropej/article-abstract/55/4/225/1672421.

Roganovic J, Starinac K (2018). Iron deficiency anemia in children. Curr Topics Amenia. 1-27. https://doi.org/10.5772/intechopen.69774.

Salvadori N, Ngo-Giang-Huong N, Duclercq C, Kanjanavanit S, Ngampiyaskul C, Techakunakorn P, Jourdain G (2017). Incidence of tuberculosis and associated mortality in a cohort of human immunodeficiency virusinfected children initiating antiretroviral therapy. J Pediatric Infect Dis Soc. 6(2): 161-167. https://doi.org/10.1093/jpids/piw090.

Sashindran Vk, Thakur R (2020). Malnutrition in HIV/AIDS; Aetiopathogenesis. Intech, (tourism), 13. Retrieved from https://www.intechopen.com/books/advanced-biometric-technologies/liveness-detection-in-biometrics

Shet A, Mehta S, Rajagopalan N, Dinakar C, Ramesh E, Samuel NM, Kurpad AV. (2009). Anemia and growth failure 
Ambarwati et al./ Iron Deficiency Anemia on the Child Death Related to HIV/AIDS Infection

among HIV-infected children in India: a retrospective analysis. BMC Pediatrics, 9: 1-9. https://doi.org/10.1186/1471-2431-9-37.

Sidamo NB, Debere MK, Enderis B, Misker $\mathrm{AD}$ (2017). Incidence and predictors of mortality among children on antiretroviral therapy in public health facilities of Arba Minch Town, Gamo Gofa Zone, Southern Ethiopia; Retrospective cohort study. Clin Mother Child Health. 14(3). https://doi.org/10.4172/2090-7214.1000267.

Sutcliffe CG, van Dijk JH, Munsanje B, Hamangaba F, Siniwymaanzi P, Thuma PE, Moss WJ (2011). Risk factors for pre-treatment mortality among HIV-infected children in rural Zambia: A cohort study. PLoS ONE, 6(12). https://doi.org/10.1371/journal.pone.0029294.

Wagnew F, Eshetie S, Alebel A, Tesema C, Kibret GD, Gebrie A, Abajobir AA
(2019). Burden of anemia and its association with HAART in HIV infected children in Ethiopia: a systematic review and meta-analysis. BMC Infect Dis. 1-9.

Wamalwa DC, Obimbo EM, Farquhar C, Richardson BA, Mbori-Ngacha DA, Inwani I, John-Stewart G (2010). Predictors of mortality in HIV-1 infected children on antiretroviral therapy in Kenya: A prospective cohort. BMC Pediatrics, 10: 4-11. https://doi.org/10.1186/1471-2431-10-33.

WHO (2006). Antiretrovirals for HIV: a compilation of facts and product information.

Zhao Y, Li C, Sun X, Mu W, McGoogan JM, He Y, Zhang F (2013). Mortality and treatment outcomes of China's national pediatric antiretroviral therapy program. Clinical Infectious Diseases, 56(5): 735-744. https://doi.org/10.1093/cid/cis941 